\title{
THE INTEGRAL VERSION OF POPOVICIU'S INEQUALITY
}

\section{Constantin P. Niculescu}

Abstract. T. Popoviciu [7] has proved in 1965 an interesting characterization of the convex functions of one real variable, relating the arithmetic mean of its values and the values taken at the barycenters of certain subfamilies of the given family of points. The aim of our paper is to prove an integral analogue.

Mathematics subject classification (2000): Primary 26A51; Secondary 26D15.

Keywords and phrases: Popoviciu's inequality, convex function, barycenter.

\section{REFERENCES}

[1] M. Bencze, C. P. Niculescu And F. Popovici, Convexity according to Popoviciu's inequality, Journal of Mathematical Analysis and Applications (to appear)

[2] D. S. Mitrinović, Analytic Inequalities, Springer-Verlag, Berlin and New York, 1970.

[3] C. P. Niculescu And L.-E. Persson, Convex Functions and their Applications. A Contemporary Approach, CMS Books in Mathematics, Vol. 23, Springer-Verlag, New York, 2006.

[4] C. P. Niculescu And F. Popovici, A Refinement of Popoviciu's Inequality, Bull. Soc. Sci. Math. Roum., 49, 97 (2006), 285-290.

[5] J. E. PeČarić, F. Proschan And Y. C. Tong, Convex functions, Partial Orderings and Statistical Applications, Academic Press, New York, 1992.

[6] T. Popoviciu, Sur quelques propriétés des fonctions d'une ou de deux variables réelles, Mathematica (Cluj), 8 (1934), 1-85.

[7] T. Popoviciu, Sur certaines inégalités qui caractérisent les fonctions convexes, Analele Ştiinţifice Univ. "Al. I. Cuza", Iasi, Seçia Mat., 11 (1965), 155-164.

[8] S.-E. TAKAHASI, Y. TAKAHASHI, AND S. WADA, An extension of Hlawka's inequality, Math. Inequal. Appl., 3 (2000), 63-67.

[9] Y. TAKAHASHI, S.-E. TAKAHASI AND S. WADA, A general Hlawka inequality and its reverse inequality, Math. Inequal. Appl., 12 (2009), 1-10. 